\title{
Piezogenic pedal papules
}

\author{
Dong-Lai Ma MD, Sergio Vano-Galvan MD PhD
}

A 56-year-old woman was concerned about multiple, enlarging, painless bumps that had been appearing on both of her heels for the past 8 months. The bumps appeared only when she stood and disappeared immediately upon sitting.

On examination, the papules were round, skincoloured and compressible, about $0.2-1.2 \mathrm{~cm}$ in diameter, appearing over the lateral and medial aspects of both heels (Figure 1). The patient had no personal or family history of connective tissue disorder.

Because the papules were enlarging and multiplying, we decided to perform a biopsy. Histology showed compact hyperkeratosis with an encapsulated fatty nodule protruding into the dermis (Appendix 1, available at www.cmaj.ca /lookup/suppl/doi:10.1503/cmaj.121963/-/DC1). The subcutaneous fat showed a loss of compartmentalization, likely related to thinning of the connective tissue trabeculae (Appendix 2, available at www.cmaj.ca/lookup/suppl/doi:10.1503 /cmaj.121963/-/DC1). We diagnosed piezogenic pedal papules and reassured our patient.

Piezogenic pedal papules are clinically diagnosed. The papules appear during weightbearing in up to $60 \%$ of the general population, most commonly over the medial aspect of the heel. ${ }^{1,2}$ Fewer than $10 \%$ of cases become painful, with most remaining asymptomatic. ${ }^{3}$ In people with hereditary connective tissue diseases such as Ehlers-Danlos syndrome, the papules tend to be larger and more numerous. The lesions arise from herniations of subcutaneous fat through connective tissue defects. Pain is attributed to ischemia caused by the extrusion of fat with its vasculature and associated nerves. ${ }^{3}$

Nonpainful piezogenic pedal papules are managed conservatively. For painful papules, management includes avoiding standing for prolonged periods, reducing foot trauma, using compression stockings and heel cups, weight loss, acupuncture, repeated injections of betamethasone and bupivacaine and, very rarely, surgery.,4

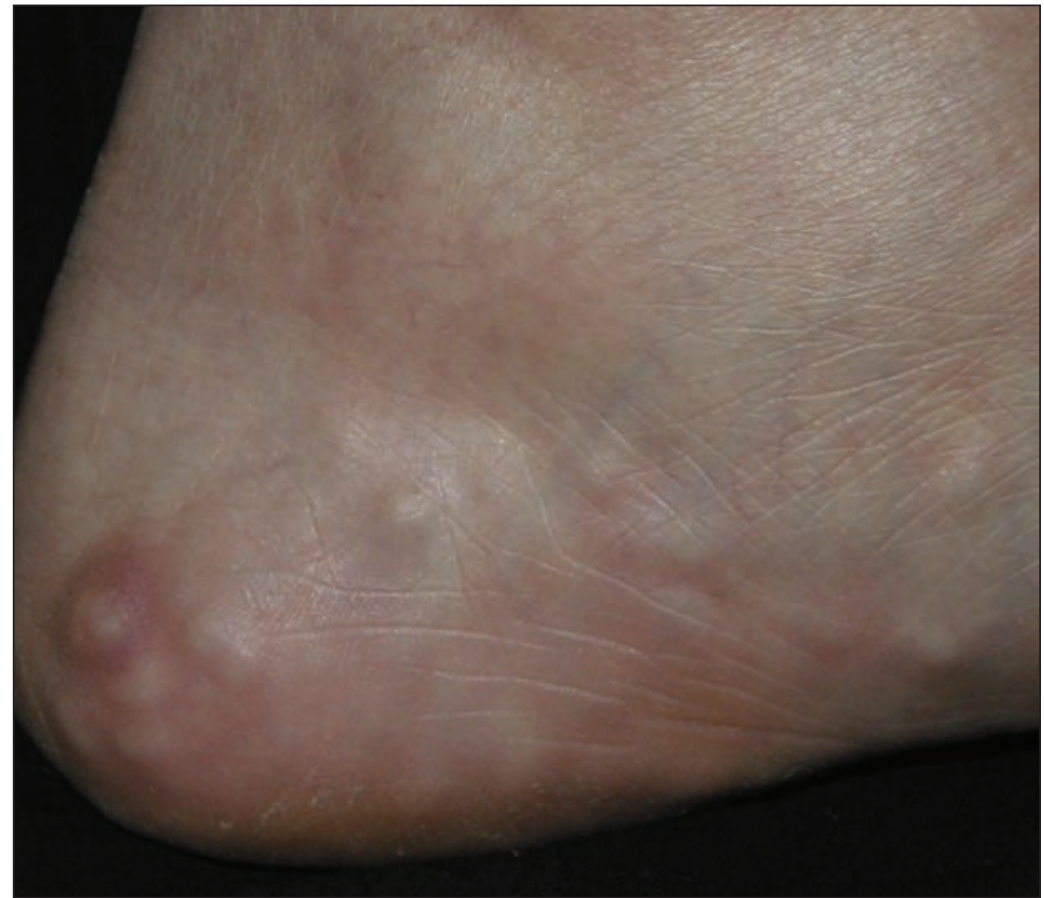

Figure 1: Photograph showing multiple soft, round, compressible, smooth skincolored papules (diameter $0.2-1.2 \mathrm{~cm}$ ) on the medial aspect of the left heel of a 56-year-old woman.

\section{References}

1. Gibney MD, Glaser DA. Piezogenic pedal papules in two family members. Cutis 1996;57:260-2.

2. Schlappner OL, Wood M, Gerstein W, et al. Painful and nonpainful piezogenic pedal papules. Arch Dermatol 1972;106:72933.

3. Redbord KP, Adams BB. Piezogenic pedal papules in a marathon runner. Clin J Sport Med 2006;16:81-3.

4. Doukas DJ, Holmes J, Leonard JA. A nonsurgical approach to painful piezogenic pedal papules. Cutis 2004;73:339-40, 346

Clinical images are chosen because they are particularly intriguing, classic or dramatic. Submissions of clear, appropriately labelled high-resolution images must be accompanied by a figure caption and the patient's written consent for publication. A brief explanation (250 words maximum) of the educational significance of the images with minimal references is required.
Competing interests: None declared.

This article has been peer reviewed.

Affiliations: Department of Dermatology (Ma), Peking Union Medical College Hospital, Chinese Academy of Medical Sciences and Peking Union Medical College, Beijing, China; Department of Dermatology

(Vano-Galvan), Hospital Ramon y Cajal, Madrid, Spain

Correspondence to: Dong-Lai Ma, mdonglai@public3.bta.net.cn

CMAJ 2013. DOI:10.1503 /cmaj.121963 